\title{
The foetus as a parasite
}

By D. J. Naismith, Department of Nutrition, Queen Elizabeth College, London, W8

One of the findings common to experiments with laboratory animals and to surveys conducted on human subjects is that the birth weight of the foetus is not substantially influenced by the protein value of the diet consumed during pregnancy (Campbell, Innes \& Kosterlitz, 1953; McGanity, Cannon, Bridgforth, Martin, Densen, Newbill, McCellan, Christie, Peterson \& Darby, 1954; Thomson, 1959). Only when severe and prolonged malnutrition is experienced before conception, is obstetrical performance impaired (Beaton, 1961). It may be concluded, therefore, that on a low plane of nutrition, the foetus lives as a parasite, the tissues of the foetus having a prior claim on the nutrients circulating in the maternal blood stream.

Of the mechanisms involved in this relationship, nothing is known, although some experiments on rats fed diets severely restricted in protein and calories have indicated that the endocrine system might be involved. Leathem (Ig66) clearly showed that reproductive failure in acute and chronic starvation is due, primarily, to a diminished synthesis and release of hormones by the pituitary gland. The importance of an intact adrenal cortex for the maintenance of pregnancy on a diet low in protein has also been demonstrated (Aschkenasy-Lelu \& Aschkenasy, 1957).

Information concerning the metabolic interactions of maternal and foetal physiology under conditions of optimum nutrition is even more difficult to come by. Perhaps the greatest obstacle to obtaining such information is the enormous difficulty involved in metabolic work with human subjects. What might seem an obvious approach in experimental animals is frequently impracticable in the case of a pregnant woman. The measurement of nitrogen balance is a good example. There are no difficulties with the rat. With the human subject, however, no nitrogen balance study throughout a 40 -week human pregnancy has been attempted. The measurement of nitrogen balance for short periods during pregnancy in a few women was undertaken in the 1930s (Hunscher, Ilummell, Erickson \& Macy, 1935), and it is from these investigations that some of our misconceptions regarding protein utilization during pregnancy have arisen.

We have no convenient and satisfactory method for measuring body composition in the human subject, while the carcass of the rat can be submitted to an accurate analysis for water, fat, protein and mineral content. Yet, when consideration is given to the fact that mothers existing on diets considered barely adequate for an adult woman produce healthy babies with birth weights that fall within the range we term 'normal', it becomes obvious that a knowledge of the changes that occur in maternal body composition during pregnancy is essential to our understanding of the relationship between mother and foetus.

In sophisticated societies, such as our own, changes in body-weight, which could be used as an indication of storage or loss of nutrients during pregnancy, are largely determined by the advice given to the mother by her obstetrician. Nevertheless, 
the view is widely held that a well-nourished woman will terminate her pregnancy with a considerable reserve of protein in her tissues (Beaton, I96r). Hytten (I964), from measurements of body water in late pregnancy, was led to the conclusion that fat, rather than protein, accumulated during pregnancy, an opinion which is supported by evidence from measurements of skinfold thickness (Taggart, I96I).

The experiments of the present author (Naismith, I 966 and unpublished results), which are described below, were undertaken in the hope of establishing a physiological basis for the assessment of protein requirements during pregnancy. In the course of this work, some original proposals as to the parasitic relationship of the foetus to the maternal organism were made. Results concerning changes in the pattern of hormone secretion in pregnant women will be presented in parallel with results from experiments with rats, in order to suggest that the same mechanisms for the protection of the foetus against the adverse effects of poor nutrition operate in man and in the rat.

Female Sprague-Dawley rats were paired, at weaning, with litter-mates of the same body-weight. Only those pairs which, during growth, remained within a few grams of each other in body-weight were used in the experiments. At approximately $220 \mathrm{~g}$ one of each pair was mated, and both were then transferred to one of three semi-synthetic diets of low, medium and high protein value. Expressed as net dietaryprotein calories \% ( $\mathrm{NDpCal} \%$ ), the calculated values of the experimental diets were 6.0 , 10.0 and 13.0 respectively.

The experiment was terminated after $2 \mathrm{I}$ days to enable an accurate record of litter size to be made. A constant volume ( $10 \mathrm{ml}$ ) of blood was taken from each rat, and the uterus, the liver and the gastro-intestinal tract were excised and weighed. The stomach and intestines were returned to the carcass after washing. The maternal carcass, the liver and the products of conception were then subjected to various analyses. Any differences between the composition of the tissues of the pregnant rats and those of their unmated controls were attributed to the effects of pregnancy.

In confirmation of the results of an earlier report (Campbell et al. r953), it was found that diet had only a slight influence on reproductive performance (Table 1 ). Litter size was not affected by diet, but the weight of the individual foetus was clearly related to protein intake, although differences between groups were small. A reduction of $54 \%$ in the dietary protein value brought about a fall in mean foetal weight of no more than $1 \mathrm{\%}$. The greater birth weights of the foetuses from mothers on the high-protein diets could not be attributed to the smaller size of the litters. No correlation was found between the weight of the individual foetus and the number in the litter.

\section{Table $\mathrm{x}$. Influence of the protein value of the diet on reproductive performance}

$\begin{array}{ccccc}\begin{array}{c}\text { Diet } \\ \text { (NDPCal } \%)\end{array} & \begin{array}{c}\text { No. of } \\ \text { litters }\end{array} & \begin{array}{c}\text { No. of } \\ \text { foetuses/ } \\ \text { litter }\end{array} & \begin{array}{c}\text { Total wt of } \\ \text { litter }(\mathrm{g})\end{array} & \begin{array}{c}\text { Wt of } \\ \text { individual } \\ \text { foetus (g) }\end{array} \\ 6 \cdot 0 & \mathrm{I2} & 13 \cdot 00 & 62 \cdot 5 & 4 \cdot 8 \mathrm{I} \\ 10 \cdot 0 & \mathrm{I2} & 12 \cdot 75 & 65 \cdot 7 & 5 \cdot 15 \\ 13 \cdot 0 & 13 & 11 \cdot 53 & 62 \cdot 3 & 5 \cdot 40\end{array}$


The results of the analyses of the maternal carcasses answered one question, and posed another (Table 2). The relative failure of the diet of lowest protein value to limit the growth of the foetuses can be accounted for by the substantial contribution made to the circulating amino acid pool from the tissue proteins of the dam. This loss of lean body mass, which was, statistically, highly significant ( $P=0.00 \mathrm{I}$ ), was masked by a considerable increase in fat reserves, so that from measurements oI body-weight alone, the rat would appear to have benefited from her pregnancy.

Table 2. Food intakes and changes in the protein and fat content of the carcass due to pregnancy

\begin{tabular}{|c|c|c|c|c|c|c|c|}
\hline \multirow[b]{3}{*}{$\begin{array}{c}\text { Diet } \\
(\operatorname{NDp} C a l \%)\end{array}$} & \multirow[b]{3}{*}{$\begin{array}{c}\text { Physiological } \\
\text { status }\end{array}$} & \multicolumn{2}{|c|}{ Food intake } & \multicolumn{4}{|c|}{ Carcass composition } \\
\hline & & & Net & \multicolumn{2}{|c|}{ Protein } & \multicolumn{2}{|c|}{ Fat } \\
\hline & & $\begin{array}{c}\text { Total } \\
(\mathrm{g})\end{array}$ & $\begin{array}{l}\text { protein } \\
(\mathrm{g})\end{array}$ & g & $\begin{array}{c}\% \\
\text { change }\end{array}$ & $g$ & $\begin{array}{c}\% \\
\text { change }\end{array}$ \\
\hline 6.0 & Non-pregnant & $3 I I$ & I $9^{\circ} \mathbf{I}$ & $4 I \cdot 5$ & & $28 \cdot 9$ & \\
\hline & Pregnant & 364 & $22 \cdot 3$ & $39^{\circ}$ & -6.0 & $35^{\circ} 0$ & $+2 I \cdot I$ \\
\hline $10 \cdot 0$ & Non-pregnant & 289 & $29 \cdot 6$ & $4 \cdot 1 \cdot 4$ & & $25 \cdot 3$ & \\
\hline & Pregnant & $36 r$ & 36.9 & $42 \cdot 0$ & $+\mathrm{I}-4$ & $36 \cdot 5$ & +44.4 \\
\hline $13 \cdot 0$ & Non-pregnant & 309 & $4 \cdot \mathbf{I}$ & $4 I \cdot 4$ & & $26 \cdot 8$ & \\
\hline & Pregnant & 368 & $48 \cdot 9$ & $41 \cdot 6$ & +0.6 & $36 \cdot 2$ & +34.9 \\
\hline
\end{tabular}

On the diets of higher protein value, no differences were found between the amounts of protein in the carcasses of pregnant and non-pregnant rats (Table 2). Futhermore, the difference between the carcass protein of pregnant rats fed the diets of $\mathrm{NDpCal} \% 6.0$ and $\mathrm{I}_{3} .0$ was $2.6 \mathrm{~g}$ only, although the latter group had consumed an additional $26 \mathrm{~g}$ of net dietary protein (i.e. potentially useful protein) in the course of pregnancy. This enormous discrepancy between the protein retained in the carcass and the additional exogenous protein available for tissue anabolism provides unequivocal evidence that the rat is unable to store protein in late pregnancy. It would appear that the dietary protein consumed in excess of the requirements for the nourishment of the foetus, for maintenance and for enlargement of the tissues involved in reproduction, is stored in the body as fat.

After $\mathrm{I}_{4}$ days of gestation, the gain in body-weight due to pregnancy was approximately $40 \mathrm{~g}$, and was similar for all three dietary groups. At this time, the rise in blood volume and the weight of the products of conception would together account for no more than $7 \mathrm{~g}$. The remainder of the increment in body-weight thus represents a storage of nutrients.

The question raised by the results summarised in Table 2 is whether the tissues of the pregnant rat are as unresponsive to different levels of protein intake as those of the non-pregnant animal, or whether part of the gain in early pregnancy is due to protein.

In an experiment of similar design to the one described above, pregnant and nonpregnant rats were maintained for $\mathbf{r}_{4}$ days on the diet of NDpCal $\% \mathbf{1 0} 0$, then killed. The viscera and uteri were dissected from all animals and these tissues and the carcasses were analysed for nitrogen. Comparisons were then made between the nitrogen content of the tissues of the pregnant rats and their controls, and the gains 
due to pregnancy were calculated. In Table 3 the partition of the additional nitrogen retained in early pregnancy is shown along with similar values calculated for animals fed the same diet for the whole of pregnancy.

Table 3. Distribution of additional nitrogen retained by pregnant rats maintained on a diet of NDPCal \% Io (nine pairs at day I 4 ; twelve pairs at day 21)

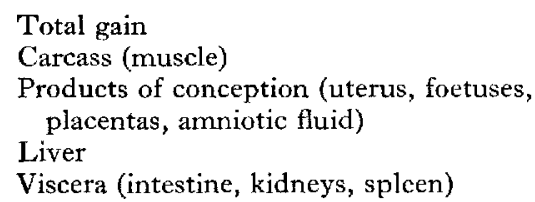

\begin{tabular}{ccrc} 
After 14 days & \multicolumn{2}{c}{ After 21 days } \\
mg & $\%$ & mg & $\%$ \\
748.6 & & 1405.9 & \\
500.5 & 66.9 & 60.0 & $4 \cdot 3$ \\
131.7 & 17.6 & 1185.6 & 84.3 \\
& & & \\
85.6 & 11.4 & 125.1 & 8.9 \\
30.8 & 4.1 & 35.2 & 2.5
\end{tabular}

After 14 days on diet, the pregnant rat had retained approximately $750 \mathrm{mg}$ nitrogen more than her non-pregnant control. The greater part of this nitrogen was found in the muscle tissue (carcass) of the dam, and represented an increase of $8.5 \%$ in lean body mass. Seven days later, although the total gain in nitrogen had almost doubled, no significant amount of the nitrogen retained in early pregnancy remained in the carcass; at term, the greater part of the nitrogen was found in the products of conception.

From this study of the changes in the composition of the maternal body over the entire period of gestation, it can be seen that the metabolism of protein proceeds in two phases. During the first (anabolic) phase, a reserve of protein and energy is built up at a time when competition from the foetus is minimal. During the second (catabolic) phase, the period of rapid foetal growth, protein reserves are withdrawn, while fat deposition continues. The catabolism of maternal protein occurs irrespective of the level of protein intake.

The transition, in the maternal organism, from a state of protein anabolism to one of protein catabolism may be explained in terms of the known metabolic effects of the hormones which participate in the control of pregnancy. The analyses of the livers from pregnant and non-pregnant rats gave some important clues as to which hormones might be involved (Table 4 ).

Table 4. Changes in the composition of the liver of rats maintained on a diet of NDPCal \% Io during pregnancy (nine pairs at day $\mathrm{1} 4$; twelve pairs at day $2 \mathrm{I}$ )

$\begin{array}{lcc} & \text { After I4 days } & \text { After } 2 \text { I days } \\ \text { Weight } & (\%) & (\%) \\ \text { Protein } & +34 \cdot 1 & +77 \cdot 0 \\ \text { Phospholipids } & +32 \cdot 0 & +55.1 \\ \text { RNA } & +36.0 & +62.6 \\ \text { Neutral fat } & * & +64.1 \\ & \text { *Value not determined. } & +391.5\end{array}$

After 2 weeks of gestation, an increase was found in all the major cytoplasmic constituents of the liver. During the final week, further changes occurred, of which two were of particular interest. Firstly, the amount of protein in the liver was greatly increased, although protein was being lost from the muscles. This was 
particularly noticeable in the case of the rats fed the low-protein diet. These animals terminated pregnancy with a net loss of $6.0 \%$ of their muscle protein, while liver protein rose by $20 \%$. Secondly, the changes in protein, phospholipids and RNA were similar in degree and varied within fairly narrow limits. In comparison, the rise in neutral fat content (total lipids-phospholipids) was of a different order of magnitude, and ranged from $80 \%$ to $800 \%$. It was, however, noticed that the rats which produced the greatest number of foetuses had the fattiest livers, and analysis of variance revealed a highly significant relationship between the percentage increase in maternal liver fat and the number of foetuses at term $(P=0.00 \mathrm{I})$.

The redistribution of maternal body protein which occurs in late pregnancy, is consistent with the action of two groups of hormones, the adrenal corticosteroids and the oestrogens.

It has long been established that the glucocorticoids have a catabolic effect on the tissue proteins of man (Sprague, Mason \& Power, I95I). Likewise, the injection of cortisone into the rat has been shown to cause a loss of protein from the carcass, the extent of which is unaffected by dietary protein intake, and a gain in liver protein and RNA (Goodlad \& Munro, 1959).

Oestradiol benzoate, administered in amounts equivalent to the level of secretion in late pregnancy, was reported to have a catabolic action in women (Laroche \& Trémolières, 1948), while treatment of rats with oestrogens results in a rise in nitrogen excretion, an increase in liver weight and protein content, and hypertrophy of the adrenal and pituitary glands (Aschkenasy-Lelu \& Aschkenasy, 1959).

The similarity between the actions of these steroids in the metabolism of protein was explained by the demonstration that oestradiol benzoate, injected into normal rats, increased the formation and secretion of ACTH by the pituitary (Gemzell, 1952). Since adrenalectomy or hypophysectomy abolishes the effect of oestrogen administration, it appears that the catabolic action of these hormones is exerted through the hypophyso-adrenocortical system (Fry, Miller \& Long, I942).

The production of a number of hormones is greatly increased in late pregnancy. The curve for the excretion of the metabolites of progesterone in women lies parallel with the weight curve for the placenta, the site of progesterone synthesis (Brown, 1957). The influence of progesterone on the metabolism of protein in healthy premenopausal women has not been investigated, but, since this hormone has been shown to have anabolic properties in the female rat (Hervey \& Hervey, r 964), its involvement in the redistribution of nitrogen in the maternal tissues may be discounted.

A similar relationship has been noted between the human foetal growth curve and the excretion curve for the oestrogens, the synthesis of which requires the participation of the foetal adrenal cortex as well as the placenta (Frandsen, 1963). Furthermore, there is a considerable body of evidence for an increased secretion of adrenocorticosteroids in late pregnancy, both in the rat and in women (Herring, I920; Hytten \& Leitch, 1964; Gemzell, I953; Doe, Zinneman, Flink \& Ulstrom, I960).

On the basis of the known physiological effects of the various hormones secreted 
in late pregnancy, a scheme is proposed for the endocrine control of protein metabolism which accounts for the high degree of independence of an exogenous supply of protein enjoyed by the foetus (Fig. I). The secretion of oestrogens by the developing foetus/placenta would stimulate, indirectly, the synthesis of corticosteroids by the maternal adrenal gland. The corticosteroids would, in turn, initiate and maintain the catabolism of maternal muscle protein, thus ensuring a continuous supply of amino acids for the synthesis of foetal proteins. The relative deficiency of insulin or reduced sensitivity to insulin, which occurs in late pregnancy, in women as well as in the rat (Hytten \& Leitch, 1964 ; Scow, Chernick \& Brinley, 1964) would reinforce the state of protein catabolism; the action of insulin has been shown to be the converse of that of the corticosteroids (Munro, 1956).

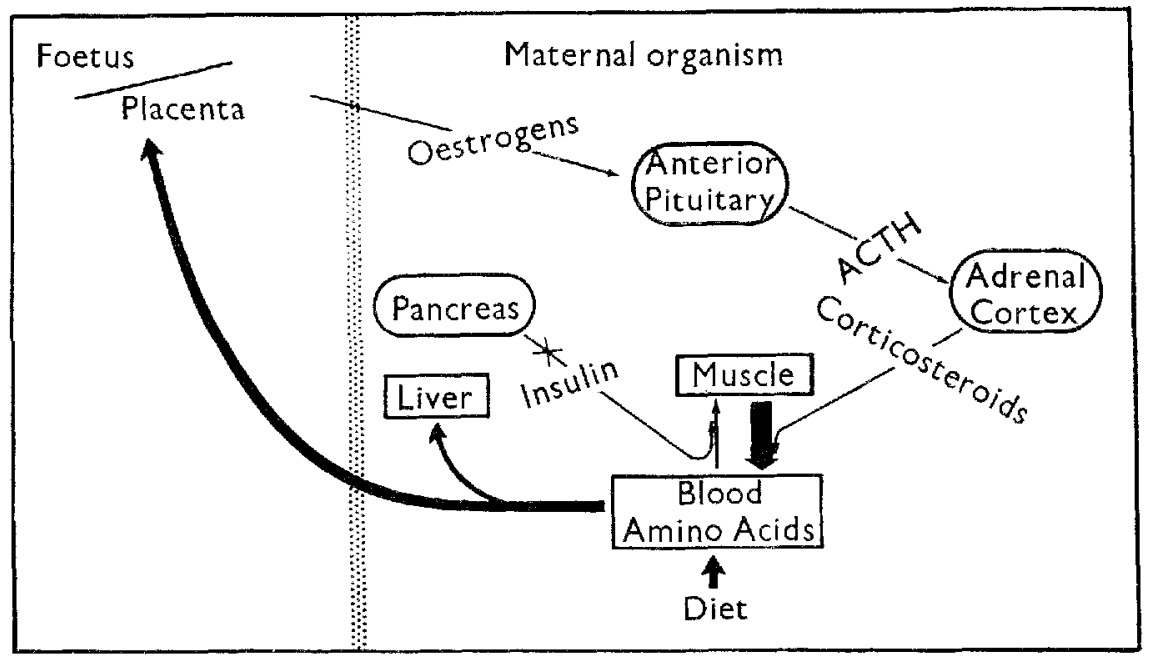

Fig. 1. Scheme proposed for the hormonal control of protein metabolism in late pregnancy.

The alterations in the lipid metabolism of the liver which occur in the pregnant rat lend support to the hypothesis outlined above. The relationship found between the increase in maternal liver fat and the number of foetuses at term clearly pointed to the interaction of a placental hormone.

In one of the few experiments in which the cumulative effect of the simultaneous intensification and suppression of different endocrine activities has been studied, Gillman \& Gilbert $\left(195^{8}\right)$ reported that the production of a fatty liver, in baboons, by corticosteroids in conjunction with the withdrawal of insulin could be greatly accelerated by the administration of oestradiol benzoate. Gillman's experimental system was very similar to the one outlined above.

We still know very little about the metabolic effects of the hormones involved in the regulation of pregnancy, and much less about the synergisms and antagonisms that exist between the different endocrine systems. It is by experimenting in this field that our curiosity about the control exerted by the foetus over its food supplies will ultimately be satisfied. 


\section{REFERENCES}

Aschkenasy-Lelu, P. \& Aschkenasy, A. (1957). Archs Sci. physiol. rx, Iz5.

Aschkenasy-Lelu, P. \& Aschkenasy, A. (1959). Wld Rev. Nutr. Diet. I, 29.

Beaton, G. H. (г 96т). Fedn Proc. Fedn Am. Socs exp. Biol. 20, Suppl. 7, p. 196.

Brown, J. B. (1957). F. Endocr. 16, 202.

Campbell, R. M., Innes, I. R. \& Kosterlitz, H. W. (I953). F. Endocr. 9, 68.

Doe, R. P., Zinneman, H. H., Flink, E. B. \& Ulstrom, R. A. (1960). F. clin. Endocr. Metab. 20, 1484,

Frandsen, V. A. (1963). The Excretion of Oestriol in Normal ITuman Pregnancy. Copenhagen:

Munksgaard.

Fry, E. G., Miller, M. \& Long, C. N. H. (1942). Endocrinology 3o, Srozg.

Gemzell, C. A. (1952). Acta endocr., Copenh. II, 221.

Gemzell, C. A. (1953). \%. clin. Endocr. r3, 898 .

Gillman, J. \& Gilbert, C. (1958). Br. med. F. i, 57.

Goodlad, G. A. J. \& Munro, H. N. (1959). Biochem. F. 73, 343.

Herring, P. T. (x920). Br. med. 7. ii, 886 .

Hervey, G. R. \& Hervey, E. (I 964). F. Endocr. 3o, vii.

Hunscher, H. A., Hummell, F. C., Erickson, B. N. \& Macy, I. G. (1935). F. Nutr. ro, 579.

Hytten, F. E. (1964). Proc. int. Congr. Nutr. vi. Edinburgh, p. 59.

Hytten, F. E. \& Leitch, I. (I964). The Physiology of Human Pregnancy. Oxford: Blackwell Scientific Publications.

Laroche, G. \& Trémolières, J. (I948). Annls Endocr. 9, 7 I.

Leathem, J. H. (1966). 7. Anim. Sci. 25, 68S.

McGanity, W. J., Cannon, R. O., Bridgforth, E. B., Martin, M. P., Densen, P. M., Newbill, J. A., McCellan, G. S., Christic, A., Peterson, J. C. \& Darby, W. J. (1954). Am. Э. Obstet. Gynec. $67,50 \mathrm{I}$

Munro, H. N. (1956). Scot. med. F. i, 285.

Naismith, D. J. (1966). Metabolism 15, 582 .

Scow, R. O., Chernick, S. S. \& Brinley, M. S. (1964). Am. F. Physiol. 2o6, 796.

Sprague, R. G., Mason, H. L. \& Power, M. H. (195I). Recent Prog. Horm. Res. 6, 3 I 5.

Taggart, N. (rg6r). Proc. Nutr. Soc. 20, xxx.

Thomson, A. M. (1959). Br. F. Nutr, 13, 509.

\section{Pathological and experimental studies of intrauterine malnutrition}

\section{By J. S. Wigglesworth, Institute of Child Health, Hammersmith Hospital, Wr2}

It has long been recognized that there may be considerable variations in birth weight of individual foetuses within litters of animals such as pigs, mice and rabbits. Several workers have investigated the factors responsible for variations in birth weight with litter size and with the position of runts within the uterus (Eckstein, McKeown \& Record, 1955; McLaren \& Michie, I960). As there is not normally any suggestion that individuals within a litter were conceived at different times the differences are accepted as reflecting variations in intrauterine growth rate.

Only in the last 20 years, however, has it become generally recognized that similar variation in intrauterine growth rate may occur in man, who has an average litter size only fractionally above one. Delayed recognition of variations in intrauterine growth rate in man (particularly intrauterine growth retardation) has largely been due to lack of objective evidence of time of conception. As birth weight was the only entirely objective parameter of maturity available any baby of $2.5 \mathrm{~kg}$ birth weight or less was until recently by definition a premature baby. There was 